\title{
PENGUJIAN PARTIAL DISCHARGE KONFIGURASI ELEKTRODA JARUM-PLAT PADA ISOLASI UDARA MENGGUNAKAN METODE ELEKTRIK; DETECTING IMPEDANCE (RC)
}

\author{
Alyssa Diva Mustika ${ }^{1}$ Riyani Prima Dewi ${ }^{2}$ \\ ${ }^{1}$ Teknik Tenaga Listrik, Institut Teknologi Bandung \\ 2Teknik Elektronika, Politeknik Negeri Cilacap \\ ${ }^{1} \mathrm{Jl}$ Taman Sari 64 Bandung 40116 \\ ${ }^{2}$ Jl Dokter Soetomo No.1, Cilacap 53212 \\ email: ${ }^{1}$ alyssadivava@gmail.com, ${ }^{2}$ riyanipdewi@ gmail.com
}

\begin{abstract}
Partial discharge (peluahan sebagian) merupakan suatu fenomena yang terjadi pada tegangan tinggi. Pengukuran Partial Discharge (PD) sangat penting untuk mengetahui kondisi suatu isolasi. Pada percobaan yang dilakukan kali ini adalah pengukuran partial discharge menggunakkan metode detecting impedance $(R C)$ dengan elektoda jarum-plat jarak 1 cm dan isolasi udara. Pengukuran Background Noise (BGN) dilakukan sebelum memulai percobaan untuk membedakan antara sinyal noise dengan sinyal PD yang akan diukur. Dari percobaan didapatkan hasil bahwa Partial Discharge Inception Voltage (PDIV) adalah PD yang muncul pertama kali, dalam percobaan ini PD negatif muncul terlebih dahulu saat tegangan sumber $3.32 \mathrm{kV}$, dengan rise time $0.1 \mu \mathrm{s}$ dan fall time sekitar $0.25 \mu$ s. Saat tegangan sumber dinaikkan menjadi $4.3 \mathrm{kV}$, muncul $P D$ negatif dengan rata rata jarak munculnya $83.6 \mu$ s muncul PD positif dengan rata rata jarak munculnya $89.5 \mu$ s.
\end{abstract}

Kata kunci: Partial Discharge, Detecting Impedance, Isolasi Udara, Elektroda Jarum-Plat.

\section{PENDAHULUAN}

Penggunaan energi listrik saat ini telah meningkat dengan Isolasi adalah salah satu bentuk peralatan tegangan tinggi yang berfungsi sebagai tahanan atau pelindung agar tidak terjadi tembus yang tidak diinginkan. Secara umum isolasi dibagi menjadi 3 (tiga) macam yaitu isolasi padat, cair dan gas. Udara termasuk isolasi jenis gas yang banyak digunakan untuk mengisolasi peralatan listrik tegangan tinggi. Isolasi berfungsi memisahkan dua atau lebih penghantar listrik yang bertegangan, sehingga antara penghantar tidak terjadi lompatan api (flash over) atau percikan api (spark over). Kemampuan isolasi dalam menahan tegangan mempunyai batas-batas tertentu sesuai dengan material penyusun dan lingkungan sekitarnya. Apabila tegangan yang diterapkan melebihi kuat medan isolasi maka akan terjadi tembus atau breakdown yang menyebabkan terjadinya aliran arus antara peralatan tegangan tinggi.

Memahami proses Partial Discharge dan korelasinya terhadap proses fisik yang menyebabkan terjadinya partial discharge, merupakan salah satu cara untuk mengetahui kondisi isolasi dan mendiagnosis proses penuaan pada peralatan insulasi. Maka pemodelan dan simulasi komputer terhadap Partial Discharge dalam isolasi udara sangat berguna untuk memahami fenomena tersebut[1]. Pada percobaan ini akan dilakukan pengukuran dan analisa dari kemunculan Partial discharge pada objek uji. Objek uji yang digunakan adalah elektroda jenis Jarum-Plat. Pengaturan elektroda ini merupakan pengaturan yang paling umum untuk investigasi pelepasan parsial karena mampu menghasilkan medan divergen yang sangat tinggi di sekitar ujung jarum[1]. Data PD disajikan dalam bentuk pola $\varphi$-q-n dan $\varphi-v$ di mana $\varphi$ adalah sudut fase kemunculan PD, $\mathrm{q}$ besaran PD dan $\mathrm{n}$ adalah nomor pulsa PD. Berdasarkan karakteristik pelepasan, diusulkan suatu rangkaian ekivalen listrik.

\section{PARTIAL DISCHARGE}

\subsection{Penyebab Partial Discharge}

Definisi Partial Discharge (IEC 60270) adalah suatu fenomena peluahan listrik secara lokal yang menghubungkan secara parsial atau sebagian dari isolasi di antara konduktor dan yang terjadi baik di permukaan konduktor maupun di dalam konduktor (void). Peluahan ini dapat terjadi pada suatu penghantar (konduktor) dalam waktu singkat, baik pada jarak dekat maupun pada jarak yang jauh.

Partial Discharge (PD) dapat terjadi pada bahan isolasi padat, bahan isolasi cair maupun bahan isolasi gas. Secara umum Partial Discharge dapat disebabkan oleh adanya konsentrasi stress elektrik setempat pada isolasi. Ada 3 hal utama yang dapat menjadi sumber terjadinya PD, yaitu Internal PD (adanya rongga di antara dielektrik atau di dalam dielektrik tertentu), Corona PD (terjadi di sekitar konduktor) dan Surface PD (terjadi pada permukaan karena kontaminasi). Adapun penyebab dari terjadinya PD adalah sebagai berikut[2]:

a. Internal PD

Internal PD disebabkan oleh karena adanya rongga dalam bahan isolasi yang biasanya di isi udara (void). Dimana bentuk, ukuran dan posisi void dalam bahan isolasi sangat mempengaruhi besar dan jumlah PD.

Fenomena void yang berisi udara dapat muncul di dalam isolasi selama proses pabrikasi, transportasi, instalasi dan operasi. Void dalam bentuk electrical

1. Arduino Uno sebagai pengatur otomatis on/off pada lampu.

2. Node Mcu sebagai pengatur manual on/off pada lampu melalui jaringan nirkabel.

3. Relay sebagai saklar sebelum menuju output

4. Module RTC sebagai pemberi data keterangan waktu terhadap.

treeing juga dapat muncul selama periode operasi dari isolasi polimer tegangan tinggi. Umumnya, void yang berisi udara memiliki permitivitas yang lebih rendah dari bahan isolasi padat sehingga void memiliki kekuatan tembus yang lebih rendah dari bahan isolasi dan akan tembus duluan sebelum bahan isolasi.

b. PD pada permukaan.

Discharge permukaan terjadi sepanjang permukaan dielektrik dimana terdapat kuat medan listrik, permukaan 
impedansi. Untuk mendapatkan nilai $\mathrm{Z}$ sebesar $50 \mathrm{ohm}$ dapat dibuat beberata alternative, diantarannya:

- Memasang $\mathrm{R}=50 \mathrm{ohm}$

- Membuat rangkaian Tee atau Phi discharge, tetapi jika tegangan dinaikkan maka streamer akan mulai terbentuk pada permukaan dan pola PD dapat ditemukan.

\section{c. Korona}

Korona adalah jenis PD juga tapi yang terjadi di media gas di sekitar konduktor yang berjauhan dengan isolasi jenis padat atau cair. Korona dapat menjadi sumber interferensi ketika dilakukan pengujian discharge sehingga dalam tes harus dijaga jangan sampai ada bagian yang ujungnya tajam tidak hanya pada sisi tegangan tinggi tetapi juga pada lantai area pengujian.

Selama terjadinya PD, ada beberapa fenomena yang menyertai terjadinya PD, antara lain arus impuls, radiasi cahaya panas, gelombang elektromagnetik, gelombang mekanik, dan proses kimia. Fenomena inilah yang ditangkap untuk mengetahui keberadaan PD.

\subsection{Metode Pengujian Partial Discharge[3]}

Metode pengukuran yang akan dilakukan pada diagnosis PD menggunakan dua metode, yaitu; metode konvensional (metode elektrik) dan metode non konvensional (metode non elektrik).

\subsubsection{Pengukuran PD dengan metode elektrik}

Metoda elektrik adalah pegukuran langsung tegangan pada RC Detektor berdasarkan arus bocor dari proses PD. Rangkaian berikut adalah rangkaian dasar pengukuran PD dengan Metode Elektrik.

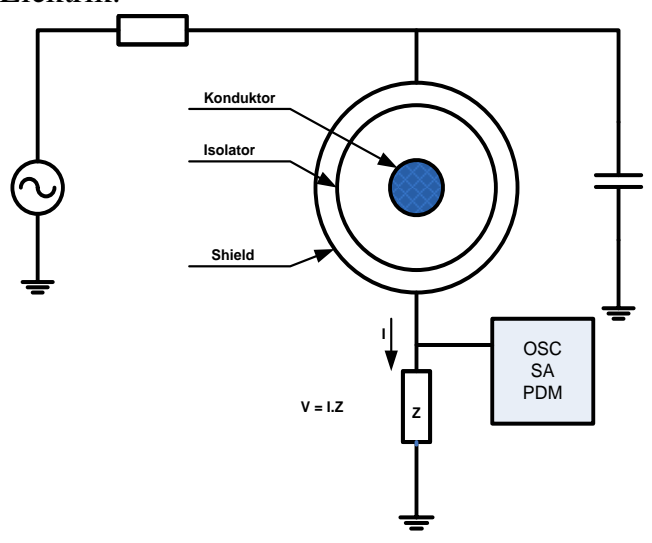

Gambar 2.1 Rangkaian dasar untuk pengukuran \& diagnosis partial discharge dengan metode elektrik

Dari gambar di atas Rangkaian dasar untuk pengukuran \& diagnosis partial discharge dengan metode elektrik terdiri dari:

- Sumber (AC, DC, atau impuls).

- Resistansi pembatas memiliki fungsi agar arus yang masuk ke dalam rangkaian tersebut tidak terlalu besar.

- Peralatan listrik tegangan tinggi.

- Coupling capacitor berfungsi untuk mengalirkan arus partial discharge pada frekuensi tinggi, sehingga arus bisa mengalir ke $\mathrm{Z}$ detecting impedance maupun osciloscop/ spectrum analyzer.

- $\mathrm{Z}$ detecting impedance berfungsi untuk mengetahui tegangan yang timbul akibat partial discharge. Nilai impedansi $\mathrm{Z}$ bedasarkan nilai impedansi peralatan listrik sebesar $50 \mathrm{ohm}$, tujuannya adalah supaya sama dengan impedansi peralatan yang akan diukur sehingga sinyal yang akan diukur tidak dipantulkan akibat perbedaan
- Osciloscop atau Spectrum Analyzer sebagai output dari

\subsubsection{Metode Non Elektrik pada Pengukuran dan Diagnosis PD}

Pengukuran dan diagnosis PD non elektrik merupakan pengukuran yang tidak mengukur besaran elektrik. Konsep pengukuran PD non elektrik adalah dengan menggunakan sejumlah peralatan sensor dan perangkat konversi dari sensor menjadi besaran yang dapat terukur pada alat ukur seperti spectrum analyzer, PD detecting maupun osiloskop.

PD yang merupakan fenomena impuls akan menyebabkan munculnya gelombang akustik, dalam kompartemen seperti GIS gelombang akustik yang cukup kuat untuk dideteksi sehingga dapat digunakan sebagai metode untuk mendeteksi PD di GIS. PD juga menyebabkan gelombang elektromagnetik dimana gelombang ini berpropagasi dari dalam sumber PD keluar bahan isolasi, PD juga menghasilkan panas yang dapat menyebabkan pemanasan disekitar isolasi dan menyebabkan kenaikan temperatur. Energi yang dilepaskan oleh PD tersebut dapat diukur menggunakan sensor sesuai dengan energinya. Partial discharge sering terjadi pada medan listrik yang sangat tinggi dan melebihi kekuatan elektrik udara.

Ada beberapa metode non konvesional untuk pengukuran dan diagnosis partial discharge, diantaranya:

a. Metode UHF (Ultra High Frequency)

Pengukuran PD menggunakan metode UHF adalah dengan mengukur gelombang yang ditimbulkan oleh partial discharge. Oleh karena gelombang frekuensi tinggi tidak dapat menembus logam, maka sensor frekuensi tinggi seperti antena loop atau dipole diletakkan sedemikian rupa sehingga dapat menerima gelombang EM yang dipancarkan PD.

b. Metode Akustik

Pengukuran PD yang memanfaatkan gelombang mekanik atau vibrasi yang ditimbulkan oleh partial discharge. Gelombang ini merambat di sepanjang permukaan material yang dianalisa. Sehingga akurasi pengukuran sangat dipengaruhi oleh kontur/permukaan material dan jarak sensor terhadap sumber partial discharge.

c. Metode Thermal

Pengukuran partial discharge menggunakan metode thermal adalah dengan mengukur temperature atau panas dari sumber partial discharge. Daerah yang terdekat dengan sumber panas adalah daerah yang memiliki temperatur yang lebih tinggi. Sehingga untuk mendapatkan hasil pengukuran yang lebih baik, maka sensor panas diletakkan sedemikian rupa sehingga diperoleh hasil ukur yang akurat.

d. Metode Optik

Pengukuran partial discharge dengan metode optik adalah dengan mengukur intensitas cahaya yang dihasilkan oleh sumber PD. Sehingga diperlukan sensor cahaya yang sensitif dan mampu menyerap cahaya dari sumber PD sebaik mungkin. Peralatan sensor optik yang dapat digunakan antara lain : Optocoupler dan Photo Multiplier Tube (PMT).

e. Metode Dekomposisi Gas

Pengukuran PD berdasarkan dekomposisi gas adalah dengan mendeteksi perubahan komposisi gas SF6 yang rangkaian di atas. 

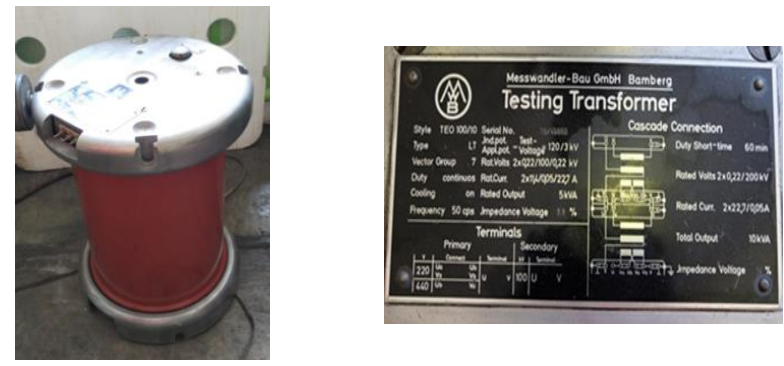

Tabel 1.1 Beberapa metode non konvesional untuk pengukuran dan diagnosis partial discharge

\begin{tabular}{|l|l|l|l|}
\hline No. & Metode & Aplikasi & Jenis Sensor \\
\hline 1 & UHF & $\begin{array}{l}\text { Mengukur Gel. EM } \\
\text { yang disebabkan } \\
\text { oleh PD }\end{array}$ & $\begin{array}{l}\text { Antena, Sensor } \\
\text { UHF }\end{array}$ \\
\hline 2 & Akustik & $\begin{array}{l}\text { Mengukur Gel. } \\
\text { Mekanik atau } \\
\text { Vibrasi yang } \\
\text { disebabkan oleh PD }\end{array}$ & Sensor Akustik \\
\hline 3 & Thermal & $\begin{array}{l}\text { Mengukur Panas } \\
\text { yang disebabkan } \\
\text { oleh PD }\end{array}$ & $\begin{array}{l}\text { Thermokopel, } \\
\text { RTD, dll }\end{array}$ \\
\hline 5 & $\begin{array}{l}\text { Mengukur intesitas } \\
\text { Cahaya yang } \\
\text { disebabkan oleh PD }\end{array}$ & $\begin{array}{l}\text { Optocoupler, } \\
\text { PMT (Photo } \\
\text { Multyphase } \\
\text { Tube) }\end{array}$ \\
\hline Disi Gas & $\begin{array}{l}\text { Mengukur } \\
\text { dekomposisi gas } \\
\text { yang disebabkan } \\
\text { oleh PD }\end{array}$ & $\begin{array}{l}\text { Sensor gas } \\
\text { (Carbon Nano } \\
\text { Tube-CNT) }\end{array}$ \\
\hline
\end{tabular}

Untuk pengukuran gelombang elektromagnetik pada metode UHF di Trafo, loop sensor diletakkan diluar tepatnya di bushing karena gel EM tidak bisa menembus dinding trafo yang terbuat dari logam.

\section{METODOLOGI PENELITIAN}

\subsection{RANGKAIAN PERCOBAAN}

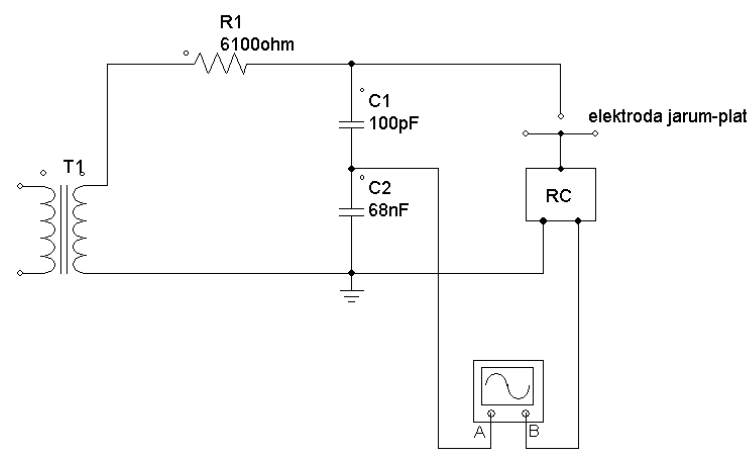

Gambar 3.1 Rangkaian percobaan Partial Discharge

\subsection{Foto dan Spesifikasi Peralatan}

Peralatan yang digunakan dan spesifikasinya:

1. Trafo Step Up, digunakan untuk mengubah dari tegangan rendah ke tegangan tinggi untuk mensuplai tegangan $\mathrm{AC}$ ke elektroda bola.
Gambar 3.2 Trafo Step Up

\begin{tabular}{|ll|}
\hline & Spesifikasi \\
\hline Merk & $:$ Messwandler \\
\hline No. seri & $: 79 / 45880$ \\
\hline Type & $:$ LT \\
\hline Vector group & $: 7$ \\
\hline Tegangan & $: 2 \times 0,22 / 100 / 0,22 \mathrm{kV}$ \\
\hline Frekuensi & $: 50 \mathrm{~Hz}$ \\
\hline Daya & $: 5 \mathrm{kVA}$ \\
\hline Impedansi & $: 3,8 \%$ \\
\hline
\end{tabular}

2. Slide Regulator, berfungsi untuk menghasilkan tegangan AC yang kemudian dihubungkan ke Trafo Step Up

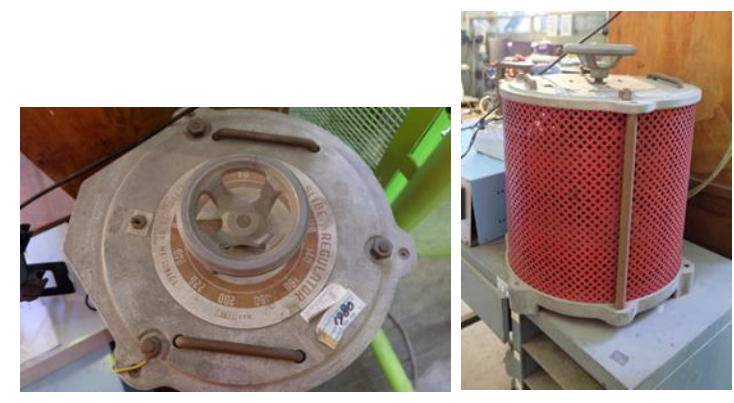

Gambar 3.3 Slide Regulator

Merk : Matsunaga

Tegangan : : $0-240 \mathrm{VAC}$

Frekuensi : $50 \mathrm{~Hz}$

Daya : $5 \mathrm{kVA}$

3. Resistor Pembatas yang berfungsi membatasi arus yang mengalir dalam rangkaian. Dalam percobaan ini digunakan $6100 \Omega$.

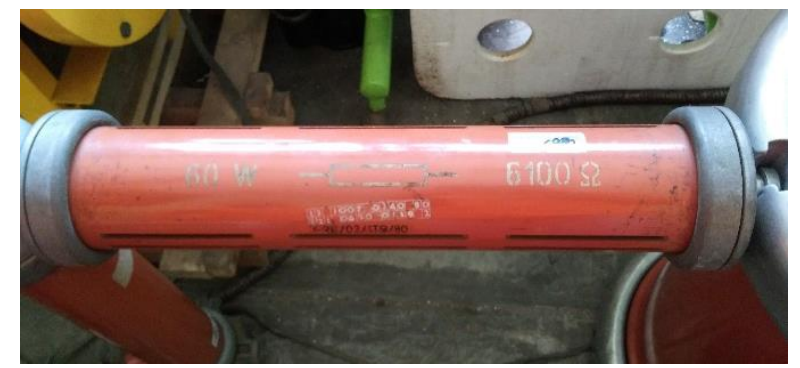

Gambar 3.4 Resistor Pembatas

Merk : Messwandler

Tahanan : $6100 \Omega$

Daya : 60 Watt

4. Coupling Capacitor, berfungsi untuk melewatkan arus frekuensi tinggi dan sebagai pembagi tegangan, sehingga diperoleh rasio $0.25 \mathrm{~V}$ pada tegangan rendah (yang terbaca 
pada multimeter) sama dengan $1 \mathrm{kV}$ pada tegangan tinggi (tegangan pada elektroda bola)
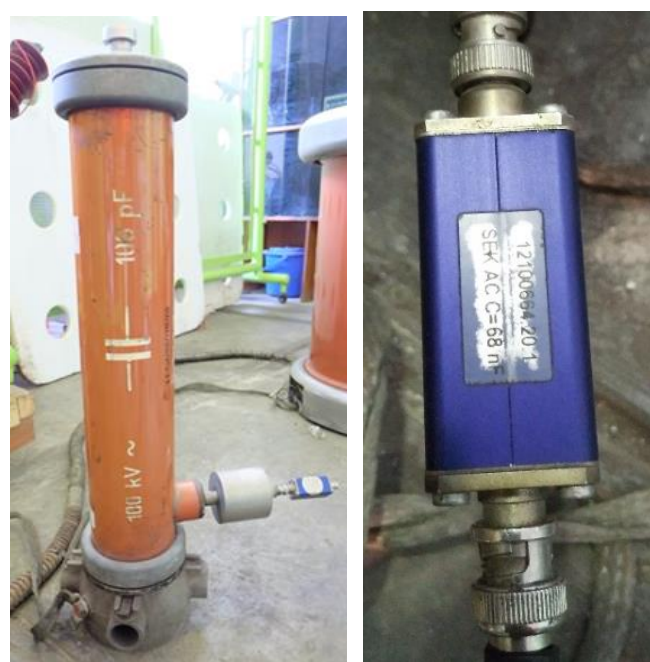

\section{Gambar 3.5 Coupling Capacitor}

Merk : Messwandler

Kapasitansi : $100 \mathrm{pF}$

Tegangan : $100 \mathrm{kV}$

5. Elektroda Jarum Plat

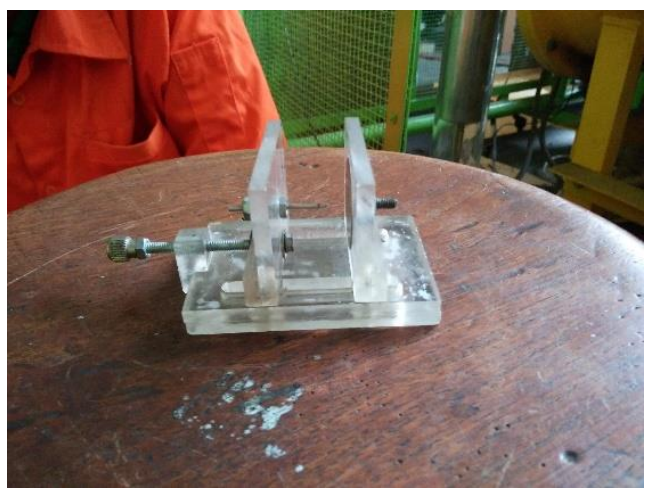

Gambar 3.6 Tabung Elektroda Bola - bola

Jarak antar elektroda diatur $10 \mathrm{~mm}$

6. RC Detector

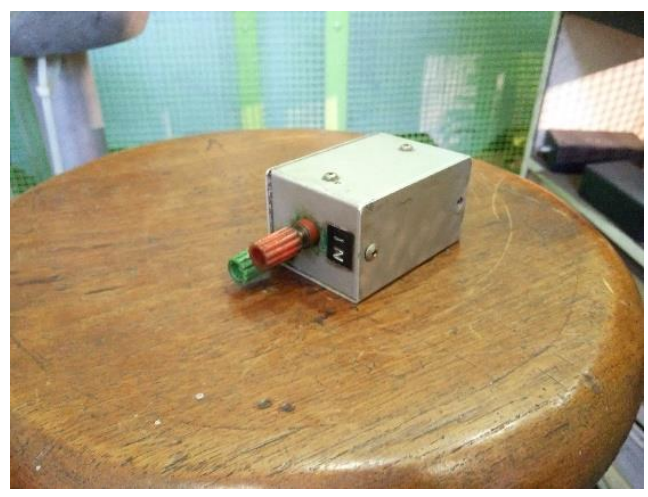

Gambar 3.7 RC Detector

7. Multimeter, berfungsi untuk mengukur nilai tegangan tembus pada rangkaian dari probe keluaran coupling capacitor.

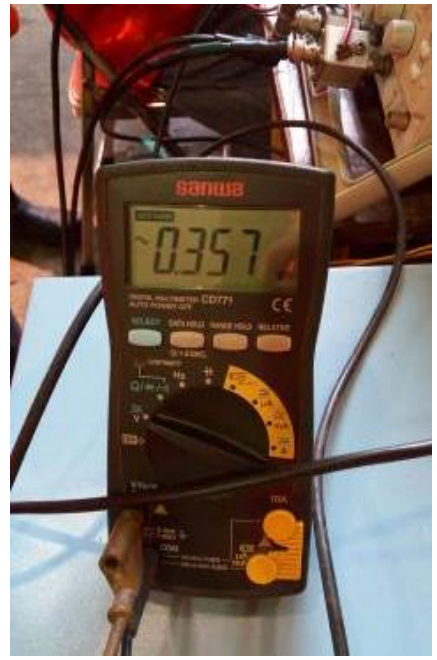

\section{Gambar 3.8 Multimeter}

Merk : Sanwa

Tipe : CD771

8. Osciloscope

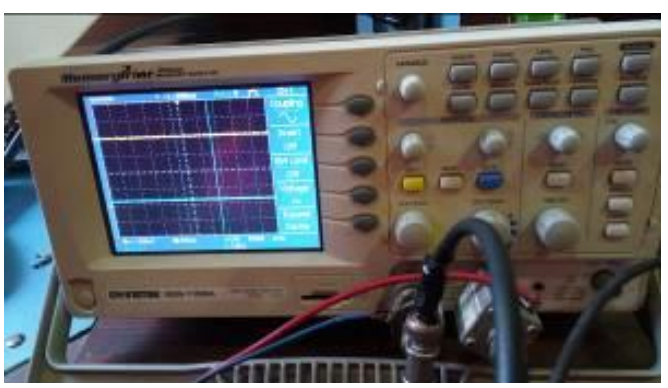

Gambar 3.9 Osciloscope

Merk : GW Instek

Tipe : GDS-1102A

\section{HASIL DAN ANALISIS}

Percobaan Partial Discharge (PD) dilakukan pada elektroda jarum-plat dengan jarak elektroda $1 \mathrm{~cm}$. Pada jarak tersebut diperoleh tegangan tembus $7.2 \mathrm{kV}$. Jadi untuk percobaan PD yang dilakukan menggunakan tegangan $<<7.2 \mathrm{kV}$ (pembacaan di multimeter $1.8 \mathrm{~V})$.

\subsection{Pengukuran Back Ground Noise (BGN)}

Pengukuran Background Noise (BGN) dilakukan sebelum memulai percobaan untuk membedakan antara sinyal noise dengan sinyal PD yang akan diukur.

Pertama yang dilakukan adalah pengukuran Back Ground Noise (BGN) didapat hasil yang ditunjukkan pada gambar 4.1 dan 4.2.

Terlihat pada gambar 4.1, sebelum sumber tegangan uji dinyalakan ternyata sudah terlihat ada noise yang terbaca pada osiloskop. Hal ini disebabkan sinyal yang terbaca oleh osiloskop merupakan sinyal frekuensi tinggi yang diloloskan oleh media detecting impedance yang bersifat sebagai high pass filter. Yaitu meloloskan sinyal berfrekuensi diatas 250 $\mathrm{kHz}$ dengan harapan sinyal fenomena partial discharge dapat ditangkap. 


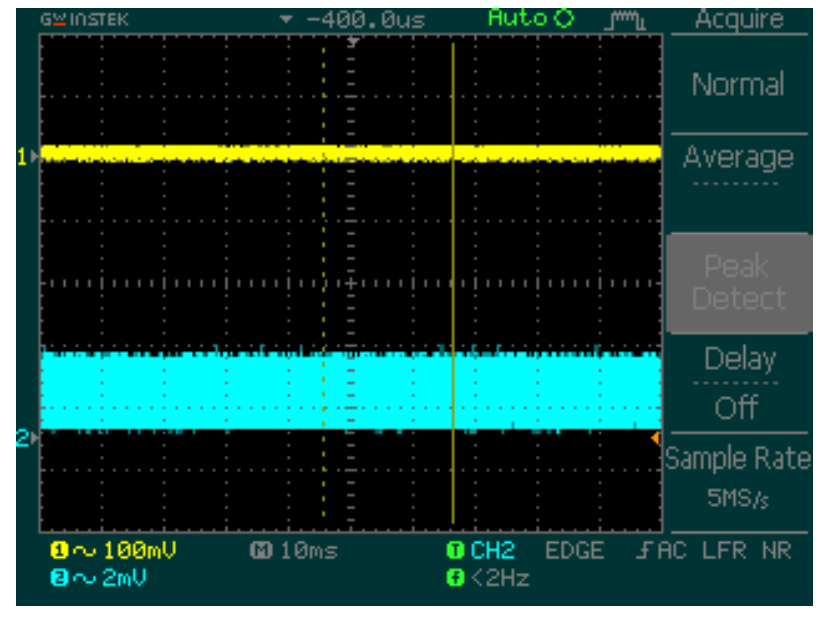

Gambar 4.1 BGN Off

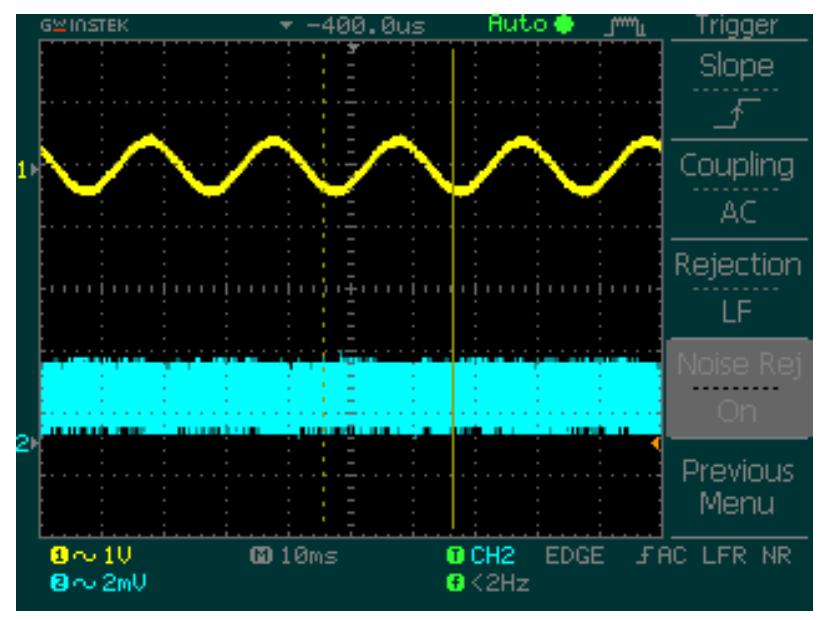

Gambar 4.2 BGN On

Noise yang terbaca osiloskop berasal dari lingkungan sekitar pelaksanaan percobaan, berupa suara mesin listrik ataupun interferensi dari gelombang elektromagnetik peralatan di laboratorium. Sedangkan pada Gambar 4.2, setelah sumber tegangan dinyalakan, terlihat bahwa gelombang sinyal input berbentuk sinusoidal yang menggambarkan bahwa sinyal input pada channel 1 merupakan sinyal input tegangan yang berasal dari jala - jala. Sedangkan pada sinyal output yang digambarkan pada channel II, terlihat bahwa noise lebih kecil. Hal ini disebabkan karena pada pengukuran kali ini time div pada pengukuran diperbesar sehingga seolah - olah noise yang muncul lebih kecil namun pada kenyataannya noise lebih besar dikarenakan adanya tambahan offset tegangan input yang berasal dari jala - jala dan noise yang muncul ketika alat belum dinyalakan.

Pengamatan background noise menjadi parameter dalam pengamatan gelombang yang muncul di osiloskop berikutnya. Tujuannya menghindari pengambilan pengamatan data gelombang partial discharge yang ternyata hanya sebatas noise.

\subsection{Pengukuran Partial Discharge Inception Voltage (PDIV)}

Untuk pengukuran Partial Discharge Inception Voltage (PDIV) didapat hasil sebagai berikut :

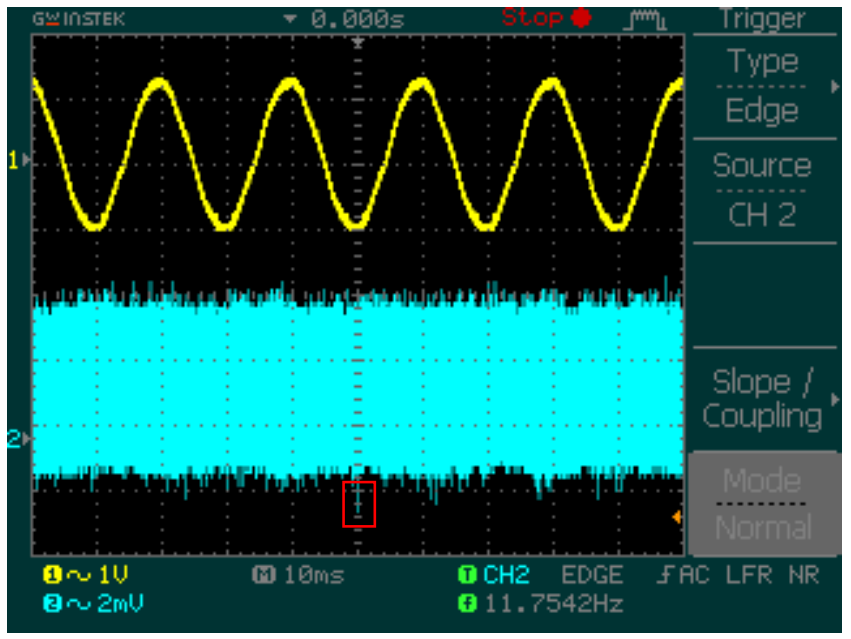

Gambar 4.3 PDIV

Seperti terlihat pada gambar 4.3 diatas, hasil yang diperoleh sesuai dengan teori yang ada, dimana PD yang pertama kali muncul adalah PD negatif. PD ini muncul pada saat tegangan sumber sekitar $3.08 \mathrm{kV}$ (hasil pengukuran pada multimeter $0.77 \mathrm{~V}$ ). Jarak antar PD sekitar $0.1999 \mathrm{~ms}$. untuk melihat $\mathrm{t}$ rise dan $t$ fall dari PD maka dilakukan pengaturan T/div untuk memperjelas grafik seperti gambar berikut ini :

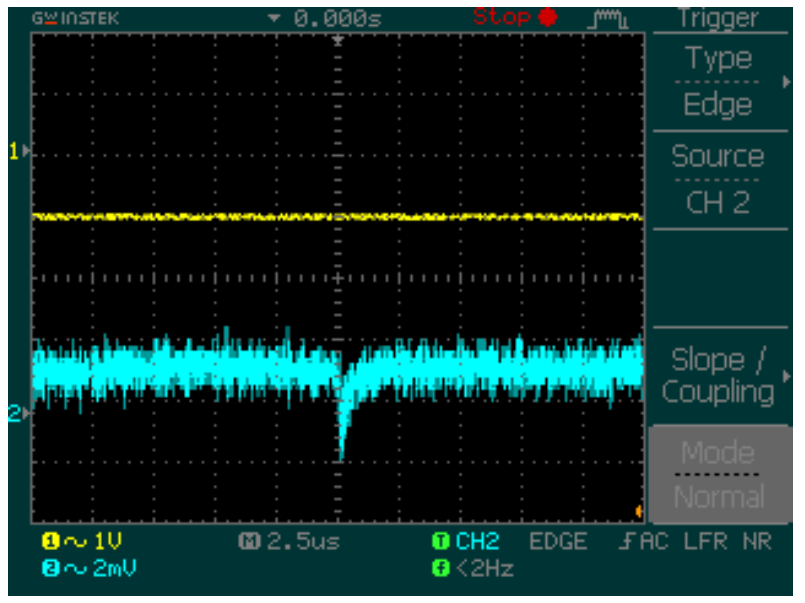

Gambar 4.4 Gambar PD negatif

Dilakukan Plot grafik untuk mempermudah analisa sebagai berikut :

\section{Plot Grafik PD Negatif}

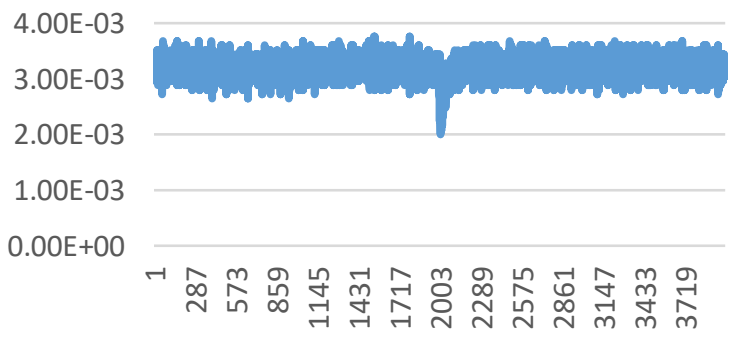

Gambar 4.5 Plot grafik PD negatif 
Dari grafik diatas terlihat bahwa rise time PD negatif sekitar $0.19 \mu$ s dan fall time sekitar $0.23 \mu$ s sehingga dapat diketahui bahwa perioda lamanya partial discharge yang terjadi pada percobaan kali ini adalah $0.04 \mu \mathrm{s}$. Berdasarkan gambar dan hasil di atas, dapat disimpulkan bahwa hasil percobaan yang dilakukan sudah sesuai dengan teori yang ada dikarenakan PDIV yang muncul pertama kali ada PD negatif. Secara teori, PDIV negatif akan muncul pertama kali karena banyaknya elektron di udara yang dihasilkan oleh emisi medan elektroda yang ada sehingga akan munculnya discharge antara muatan negatif (elektron) di udara dengan muatan positif di elektroda. Fenomena ini lebih familiar untuk disebut fenomena PD negatif. Seperti yang terlihat pada gambar berikut

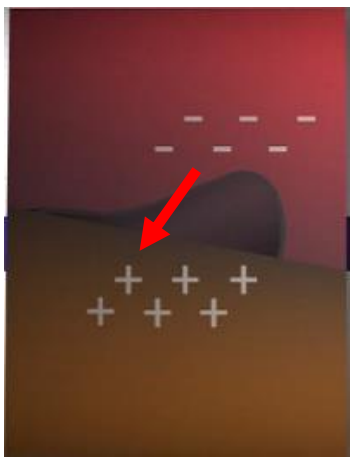

\section{Gambar 4.6 Mekanisme terjadinye PD negatif}

\subsection{Pengukuran PD Waveform}

Seperti yang telah diketahui pada bagian 4.2 bahwa setelah fenomena partial discharge negatif muncul, akan muncul fenomena partial discharge positif sehingga pada percobaan kali ini praktikan mencari nilai tegangan pada saat fenomena partial discharge positif muncul. Untuk tegangan sumber 3.76 $\mathrm{kV}$ (pengukuran pada multimeter $0.94 \mathrm{~V}$ ) diperoleh fenomena partial discharge positif dengan karakteristik partial discharge seperti terlihat pada gambar dibawah ini:

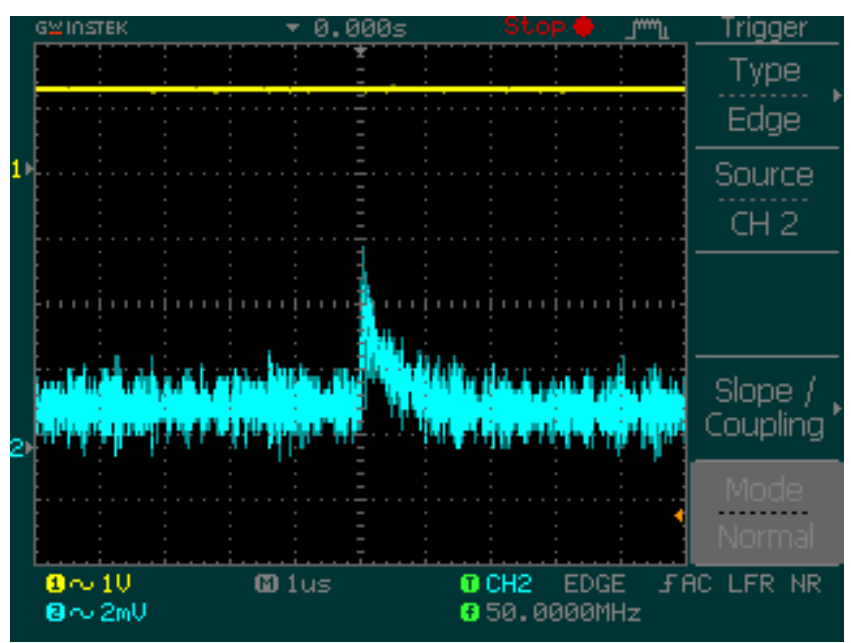

Gambar 4.7 PD Positif pada Vs=3.76 kV

Berdasarkan gambar di atas dapat terlihat bahwa terlihat bentuk gelombang partial discharge positif yang berbentuk seperti impuls. Pada fenomena ini, dapat dilihat bahwa perioda waktu dari fenomena partial discharge positif ini sangat cepat yaitu $2.1 \mu \mathrm{s}$. Jika dibandingkan dengan fenomena partial discharge negative waktu ini lebih lama. Hal ini dikarenakan dibutuhkannya waktu untuk terjadinya peluahan antara muatan positif di luar elektroda karena ketika elektroda bertegangan, elektroda mengeluarkan emisi medan yang menghasilkan muatan negatif di udara bukan muatan positif sehingga dibutuhkan waktu yang lebih lama untuk mengurai muatan negatif di elektroda untuk membuat muatan positif lebih dominan sehingga dapat terjadi peluahan positif antara udara dengan elektroda.

\subsection{Pengukuran Pola Urutan Fasa PD}

Pada percobaan ini praktikan tidak melakukan pengambilan foto secara keseluruhan dengan T/Div yang lebih besar untuk mendapatkan gambar pola fasa PD. Namun, praktikan mengambil gambar pola fasa PD negatif dan PD postif satu persatu dengan mengecilkan T/Div seperti yang terlihat pada gambar 4.4 untuk pola fasa partial discharge negatif dan 5.7 untuk pola fasa partial discharge positif

Dari percobaan ini diperoleh bahwa pada saat periode positif tegangan sumber maka muncul PD positif juga, dan pada saat periode negatif maka muncul PD Negatif. Dibandingkan dengan nilai saat PDIV, terjadi PD yang lebih besar saat tegangan sumber $3.76 \mathrm{kV}$. Rata rata jarak PD Positif yang muncul adalah $236 \mu$ s. Rata jarak PD negatif muncul adalah $234 \mu \mathrm{s}$. Berdasarkan data hasil tersebut, dapat disimpulkan bahwa data percobaan yang diperoleh sudah sesuai dengan teori karena nilai PD yang terjadi lebih besar dari PDIV dan PD negatif muncul terlebih dahulu daripada PD positif . Selain itu, dapat disimpulkan bahwa kekuatan insulasi elektroda pelat jarum adalah $3.76 \mathrm{kV}$ karena munculnya PD pada tegangan $3.76 \mathrm{kV}$ ini merupakan tanda awal kegagalan kekuatan insulasi pada suatu peralatan. Pada percobaan kali ini, terlihat bahwa tegangan tembus PD ini sudah mendekati limit tegangan tembus sehingga wajar apabila terlihat bahwa sinyal input pada channel I terganggu.

\subsection{Pengukuran PD pada $\mathrm{V}=2 \mathrm{xPD}$}

Pada bagian 4.3 dapat diketahui bahwa fenomena PD terjadi pada tegangan $3.76 \mathrm{kV}$ sedangkan limit batas dari fenomena tembus listrik yang dilakukan pada praktikum kali ini adalah $7.2 \mathrm{kV}$ sehingga apabila dilakukan pengukuran 2xPD maka tegangan sumber sudah melebihi tegangan tembus yang dibutuhkan yaitu $7.52 \mathrm{kV}$. Hal tersebut membuat praktikan memutuskan untuk tidak melakukan percobaan pengukuran dengan $\mathrm{V}=2 \mathrm{xPD}$ karena praktikan anggap terlalu berbahaya jika dilakukan.

\section{KESIMPULAN}

Dari percobaan Pengukuran Partial Discharge didapat kesimpulan sebagai berikut :

1. Detecting impedance rangkaian $\mathrm{RC}$ pada pengujian partial discharge berfungsi sebagai integrator sinyal PD untuk menghasilkan Vd. Dengan mengukur discharge paramater diantaranya magnitude, frequency dan phasa , kejadian PD pada suatu Tegangan operasi dapat dihitung.

2. Pengukuran Background Noise (BGN) dilakukan sebelum memulai percobaan untuk membedakan antara sinyal noise dengan sinyal PD yang akan diukur.

3. Partial Discharge Inception Voltage (PDIV) adalah PD yang pertama muncul, dalam percobaan ini PD negatif muncul terlebih dahulu saat tegangan sumber $3.08 \mathrm{kV}$, dengan rise time $0.19 \mu$ s dan fall time sekitar $0.23 \mu$ s dan periode terjadinya partial discharge adalah $0.04 \mu \mathrm{s}$.

4. Saat tegangan sumber dinaikkan menjadi $3.76 \mathrm{kV}, \mathrm{PD}$ muncul positif dan negatif dengan rata rata jarak munculnya PD positif $236 \mu \mathrm{s}$ dan PD negatif $234 \mu \mathrm{s}$. 
Pada percobaan kali ini metode yang dilakukan baru menggunakan Detecting Impedance. Percobaan dengan metode lain seperti antena dan HFCT perlu dilakukan untuk membandingkan hasil.

\section{REFERENCES}

[1] N. Ra and U. Khayam, "Partial discharge measurement of 4 types of electrodes configuration in air insulation using high frequency current transformer sensor," Proc. - Jt. Int. Conf. Electr. Veh. Technol. Ind. Mech. Electr. Chem. Eng. ICEVT 2015 IMECE 2015, no. c, pp. 100-105, 2016, doi: 10.1109/ICEVTIMECE.2015.7496667.

[2] Profesor Suwarno, Diagnosis Peralatan Tegangan Tinggi dan Smart Grid; Pidato Ilmiah Guru Besar Institut Teknologi Bandung Profesor, no. September. Bandung: Penerbit ITB, 2012.

[3] U. Khayam, "Modul Praktikum Partial Discharge," 2014. 